\title{
Comparative Assessment of Growth Sustainability of Germany, France, United Kingdom, and United States between 2000 and 2010
}

\author{
Natalia Victorovna Kuznetsova ${ }^{1} \&$ Ekaterina Vasilievna Kuznetsova ${ }^{2}$ \\ ${ }^{1}$ Doctor of Economics, Department of World Economy, School of Economics and Management, Far Eastern \\ Federal University, Russian Foundation \\ ${ }^{2}$ BBA, Specialist in International Economics, M.S. in National Security and Public Safety, Russian Foundation \\ Correspondence: Natalia Victorovna Kuznetsova, Suhanova St. 8, Vladivostok, 690950, Russian Foundation.
}

Received: December 30, 2014 Accepted: March 20, 2015 Online Published: May 22, 2015

doi:10.5539/ass.v11n14p235 URL: http://dx.doi.org/10.5539/ass.v11n14p235

\begin{abstract}
The results presented in this article are part of a broader experimental research focused on the examination of growth sustainability that is conducted through inequation $\Delta T-\Delta P \leq \Delta S$ conclusively developed on the basis of separate researches. This article examines growth sustainability of Germany, France, United Kingdom, and United States using time series data between 2000 and 2010. We built the inequation based on a simple initial suggestion that any country's economy benefits from balanced development between the needs of current generation and future generation. Inequation is based on three elements: $\Delta \mathrm{P}$, or population surplus and public spending dynamics is calculated for the purposes of reflecting the needs of current generation, $\Delta \mathrm{T}$, or technological surplus reflects the necessary strategic investments dynamics in economic growth of future generation, $\Delta \mathrm{S}$, or savings surplus as one of the most important components of sustainable growth of any country, is evaluated towards equilibrium of two other components. The article presents and analyses results of a broad series of calculations of all collected time series data. The results allowed us to conduct the sustainability testing and we analyzed dynamics of the sustainability elements. The article offers comparative assessment of sustainability of given countries. The conducted experimental research confirmed findings of testing of separate group of countries: mainly we concluded that the concept of a sustainable growth is in its rudimentary stage with given level of strategic application of developed economic knowledge and statistical methods towards practical use for the benefit of society.
\end{abstract}

Keywords: growth sustainability, Germany, France, United Kingdom, United States, technological progress, population expenditures, savings surplus, generation, welfare, economic growth, surplus

\section{Introduction}

Growth sustainability is defined as a balanced development that reflects needs of a current generation, but does not deprive future generations from progress and ability to sustain their own needs. The basic principle of sustainability is fair and equal share of resources (technological capacities, financial, etc.) not only inside a given generation but also among generations.

Generally, sustainability might be evaluated through different measures, especially when comparing sustainability among countries. However as the result of various statistical evaluations and extensive economic theory research the debate of what comprises the best evaluation of sustainability we can make a conclusion that the compromise must be found between three general elements: growth in consumption (especially when talking about consumption of social services provided by government in exchange for taxes) should not be smaller than technological growth (because in this case current generation gives up their welfare for the benefit of growth of future generation); if the surplus of both is relatively equal - the balance can be considered fair; the third component is savings - savings surplus is equally important for current and future generations (it serves as essential security net) and must be evaluated towards the balance between welfare and technological surplus.

Theory of sustainable growth has been discussed for a long time, for example in researches conducted by such authors as: H. Hotelling (1931), J. R. Hicks (1946), R. Solow (1974), J. Hartwick (1977), T. Page (1977), R. Turner (1988), D. Pearce, \& M. Redclift (1988), C. Conroy, \& M. Litvinoff (1988), D. Collard, \& D. Pearce (1988), M. Marien (1989), L. Hilbrath (1990), F. Harrison, \& G. Titova (1997), D. Pearce, \& E. Barbier (2000), 
M. Carr (1988), T. V. Terentieva, \& M. A. Bobireva (2011), R. Barro, \& X. Sala-I-Martin (1995). L. Brown most explicitly and fully presented basic approaches for the concept of sustainable growth in his book "Building a Sustainable Society" (1981).

We define sustainability as an ability of a system to function in circumstances close to equilibrium, in conditions of constant outside and internal disturbing influences. Growth sustainability is a concept that goes ahead of time, as technological progress and investments in future generation with necessary investments from the current generation together with essential savings safety net are components of predictable development of any given country.

\section{Methods}

This research focuses on assessment (and further comparison) of growth sustainability of Germany, France, United Kingdom, and United States based on time series data for the years between 2000 and 2010 measured through the introduced inequation:

$$
\Delta T-\Delta P \leq \Delta S,
$$

where:

$\Delta T$ is a technological surplus,

$\Delta P$ is a population surplus and public expenditures dynamics,

$\Delta S$ is a savings surplus.

$\Delta T$ for every country is calculated based on yearly data for a) volume of high-tech export, b) labor productivity, c) $R \& D$ spending, d) license royalties.

$\Delta P$ for every country is calculated based on yearly data for a) education expenditures, b) governmental social security expenditures, c) governmental expenditures on retirement, d) healthcare expenditures, e) surplus of population between 15 and 64 years old.

$\Delta S$ for every country is calculated based on yearly data for a) gross domestic income, b) quasi money (current LCU), c) cash holdings.

Dynamics of time series data represent growth rates (as oppose to calculated absolute growth). Since the growth rate for every variable is calculated based on difference between "current" and "previous" year, the presented in the paper final statistics starts from year 2001, however it is important to keep in mind that 2001 rate is a dynamics that covers the year 2000 as well.

At a later phase, we calculated statistical medians of $\Delta \mathrm{T}, \Delta \mathrm{P}$ and $\Delta \mathrm{S}$. At a final stage, inequation $\Delta T-\Delta P \leq \Delta S$ is analyzed for every year assessing growth sustainability of a given country.

\section{Results}

We collected broad range of necessary time series data, explained explicitly in Methods, and calculated growth rates dynamics for every variable of the inequation's elements. We then calculated medians of the inequation's elements and presented final results below. In order to be able to better depict situation for every country we presented the results graphically as well.

Table 1. Germany, 2000-2010. Calculation of inequation elements based on time series data, and assessment of sustainability test $\Delta T-\Delta P \leq \Delta S$

\begin{tabular}{ccccccccccc}
\hline & 2001 & 2002 & 2003 & 2004 & 2005 & 2006 & 2007 & 2008 & 2009 & 2010 \\
\hline$\Delta \mathrm{T}$ & 1,012 & 1,022 & 1,090 & 1,119 & 1,126 & 1,078 & 1,080 & 1,063 & 0,980 & 0,970 \\
$\Delta \mathrm{P}$ & 0,990 & 1,075 & 1,183 & 1,079 & 1,019 & 1,022 & 1,112 & 1,048 & 0,950 & 1,022 \\
$\Delta \mathrm{S}$ & 1,032 & 1,025 & 1,023 & 1,027 & 1,034 & 1,046 & 1,027 & 1,044 & 0,996 & 0,996 \\
$\Delta \mathrm{T}-\Delta \mathrm{P}$ & 0,022 & $-0,053$ & $-0,093$ & 0,040 & 0,108 & 0,056 & $-0,032$ & 0,015 & 0,029 & $-0,053$ \\
Conclusion & & & \multicolumn{7}{c}{ Sustainable Growth } \\
\hline
\end{tabular}

(Encyclopedia of the Nations, n.d.-a; Encyclopedia of the Nations, n.d.-b; Nation Master, n.d.-a; Nation Master, n.d.-b; Nation Master, n.d.-c; OECD, n.d.-a; OECD, n.d.-b; OECD, n.d.-c; The World Bank, n.d.-a; The World Bank, n.d.-b; The World Bank, n.d.-c; The World Bank, n.d.-d; The World Bank, n.d.-e; The World Bank, n.d.-f; The World Bank, n.d.-g; The World Bank, n.d.-h; The World Bank, n.d.-i; The World Bank, n.d.-j) 


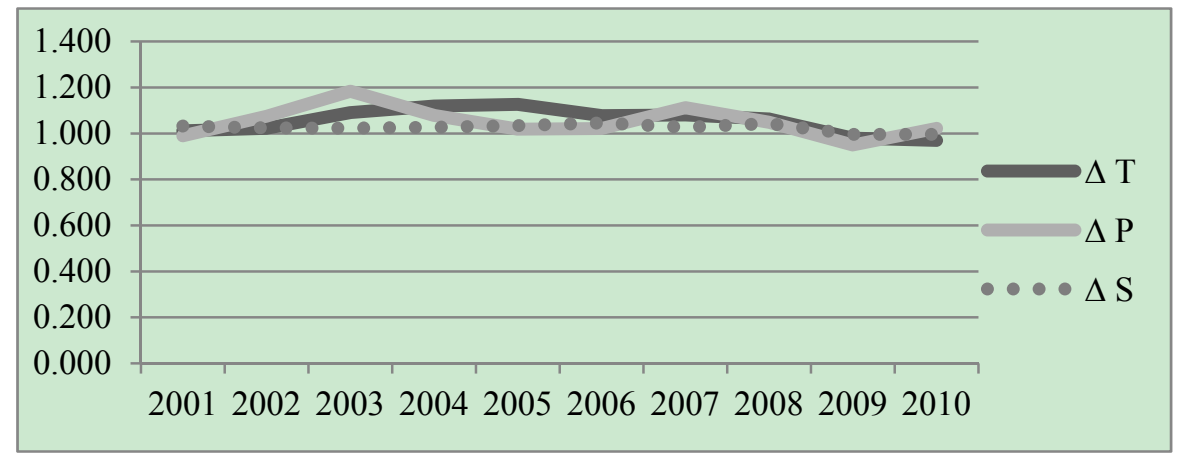

Compiled by the authors

Figure 1. Germany, 2000-2010. Sustainability elements $\Delta T, \Delta P, \Delta S$

Germany passed the sustainability test as its technological surplus minus population surplus with public spending dynamics was lower than savings surplus (see Table 1 and Figure 1). Savings surplus was the only variable that was kept on the relatively same level through the decade, which is an important economic growth factor. Population dynamics was the most fluctuating one, growing up to 2003 and going downhill till 2005, staring to grow again up to 2007, and hitting its lowest in 2009 (this maybe in relation to the world crisis). These fluctuations in surplus of population dynamics reflect the limitation of German public spending dynamics.

In the light of fluctuation seen at population dynamics, technological surplus can be viewed as relatively stable; however fluctuations of a different character took place. Speaking of technological surplus we mainly speak about perspective for a future generation and for the future growth of the country. In the case of Germany we can see that surplus has grown up till 2005 and went downhill ever since. If we compare dynamics of technological surplus and population dynamics (keeping in mind that positive sustainability testing presumes an equality of these elements), we will see that equality growth between two elements was gained only near the crisis time around 2007 both growth rates of these elements went downhill, up until then there was a considerable difference. Nonetheless, even considering all of the above - Germany passed the sustainability test.

Table 2. United Kingdom, 2000-2010. Calculation of inequation elements based on time series data, and assessment of sustainability test $\Delta T-\Delta P \leq \Delta S$

\begin{tabular}{ccccccccccc}
\hline & 2001 & 2002 & 2003 & 2004 & 2005 & 2006 & 2007 & 2008 & 2009 & 2010 \\
\hline$\Delta \mathrm{T}$ & 0,989 & 1,062 & 1,073 & 1,132 & 1,097 & 1,132 & 0,910 & 1,020 & 0,766 & 1,000 \\
$\Delta \mathrm{P}$ & 1,024 & 1,114 & 1,139 & 1,160 & 1,049 & 1,072 & 1,112 & 0,969 & 0,913 & 1,015 \\
$\Delta \mathrm{S}$ & 1,075 & 1,058 & 1,063 & 1,079 & 1,080 & 1,093 & 1,065 & 1,000 & 1,043 & 1,048 \\
$\Delta \mathrm{T}-\Delta \mathrm{P}$ & $-0,035$ & $-0,052$ & $-0,066$ & $-0,028$ & 0,047 & 0,060 & $-0,203$ & 0,051 & $-0,147$ & $-0,014$ \\
Conclusion & & & & \multicolumn{3}{c}{ Sustainable Growth } & & & &
\end{tabular}

(Index Mundi, n.d.-a; Office for National Statistics, 2011; Goodman \& Sibieta, 2006; Encyclopedia of the Nations, n.d.-a; Encyclopedia of the Nations, n.d.-b; Nation Master, n.d.-a; Nation Master, n.d.-b; Nation Master, n.d.-c; OECD, n.d.-a; OECD, n.d.-b; OECD, n.d.-c; The World Bank, n.d.-a; The World Bank, n.d.-b; The World Bank, n.d.-c; The World Bank, n.d.-d; The World Bank, n.d.-e; The World Bank, n.d.-f; The World Bank, n.d.-g; The World Bank, n.d.-h; The World Bank, n.d.-i; The World Bank, n.d.-j)

United Kingdom passed the sustainability test, however showed major fluctuations in growth rates (see Table 2 and Figure 2). Savings surplus was the least impacted by either managerial or outside factors instability, which is a positive factor considering that population surplus and public expenditure dynamics was greater than technological surplus at most of the time, with exceptions between 2004 and 2006, and short period in 2008, when technological surplus was greater. As far as technological surplus dynamics, it can be seen that it had been growing up until 2004 and remained relatively at the same level till 2006, starting 2006 there were serious fluctuations: it went downhill till 2007, picked up and started falling again in 2008, picking up again in 2009, reaching equilibrium with population dynamics in 2010. Such instability can be perhaps explained by the started crises. 


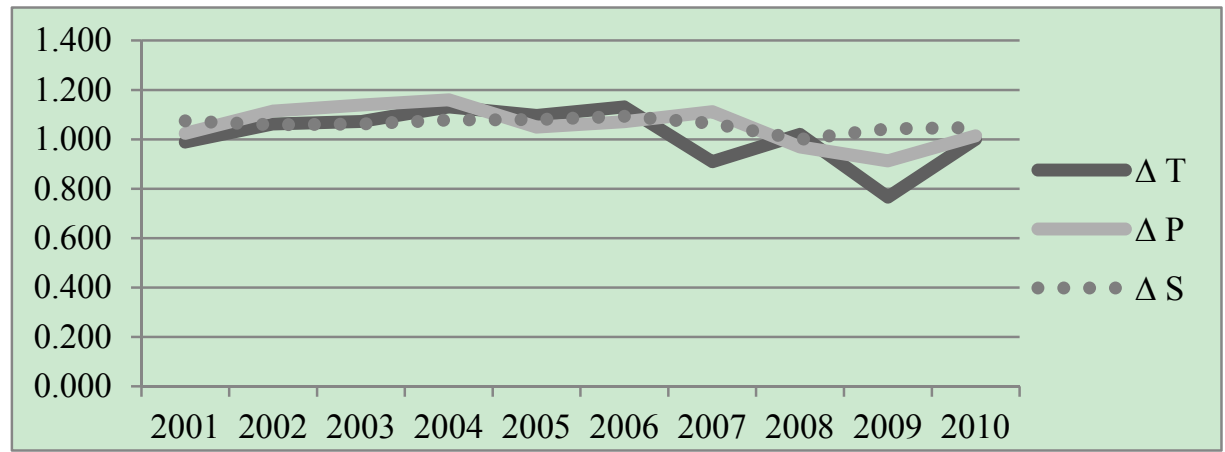

Compiled by the authors

Figure 2. United Kingdom, 2000-2010. Sustainability elements $\Delta T, \Delta P, \Delta S$

Table 3. France, 2000-2010. Calculation of inequation elements based on time series data, and assessment of sustainability test $\Delta T-\Delta P \leq \Delta S$

\begin{tabular}{ccccccccccc}
\hline & 2001 & 2002 & 2003 & 2004 & 2005 & 2006 & 2007 & 2008 & 2009 & 2010 \\
\hline$\Delta \mathrm{T}$ & 0,976 & 1,023 & 1,136 & 1,137 & 1,027 & 0,945 & 1,106 & 1,128 & 0,997 & 1,031 \\
$\Delta \mathrm{P}$ & 1,026 & 1,030 & 1,064 & 1,060 & 1,017 & 1,007 & 1,001 & 1,009 & 1,009 & 1,056 \\
$\Delta \mathrm{S}$ & 1,027 & 1,025 & 1,088 & 1,080 & 1,032 & 1,072 & 1,116 & 1,063 & 0,928 & 1,096 \\
$\Delta \mathrm{T}-\Delta \mathrm{P}$ & $-0,050$ & $-0,007$ & 0,071 & 0,077 & 0,009 & $-0,063$ & 0,106 & 0,118 & $-0,012$ & $-0,025$ \\
Conclusion & & & & & & Sustainable Growth & & & & \\
\hline
\end{tabular}

(UNData, n.d.; Index Mundi, n.d.-b; Encyclopedia of the Nations, n.d.-a; Encyclopedia of the Nations, n.d.-b; Nation Master, n.d.-a; Nation Master, n.d.-b; Nation Master, n.d.-c; OECD, n.d.-a; OECD, n.d.-b; OECD, n.d.-c; The World Bank, n.d.-a; The World Bank, n.d.-b; The World Bank, n.d.-c; The World Bank, n.d.-d; The World Bank, n.d.-e; The World Bank, n.d.-f; The World Bank, n.d.-g; The World Bank, n.d.-h; The World Bank, n.d.-i; The World Bank, n.d.-j)

France passed the sustainability test. Population surplus and public expenditure dynamics was the most stable element of the inequation for France, however technological growth had been fluctuating in a way that it seems to be almost an experimental for France (see Table 3 and Figure 3). France grew it technological surplus leaving it at the same level from 2003 to 2004, then it went down to its lowest point in 2006, which cannot be explained by drawing more attention to internal social problems because population and public expenditure dynamics remained the same. After hitting its lowest, France repeated the earlier path, picking up technological surplus up to 2007 and leaving it at the same level till 2008. Savings surplus dynamics had remained dangerously unstable.

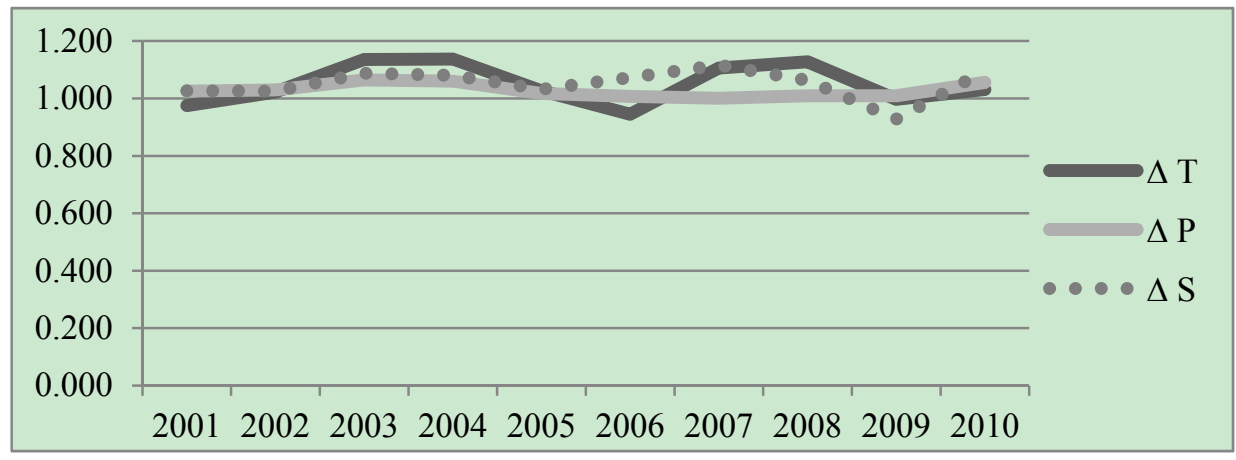

Compiled by the authors

Figure 3. France, 2000-2010. Sustainability elements $\Delta T, \Delta P, \Delta S$ 
Table 4. USA, 2000-2010. Calculation of inequation elements based on time series data, and assessment of sustainability test $\Delta T-\Delta P \leq \Delta S$

\begin{tabular}{ccccccccccc}
\hline & 2001 & 2002 & 2003 & 2004 & 2005 & 2006 & 2007 & 2008 & 2009 & 2010 \\
\hline$\Delta \mathrm{T}$ & 0,988 & 1,027 & 1,013 & 1,094 & 1,063 & 1,051 & 1,047 & 1,049 & 0,897 & 1,073 \\
$\Delta \mathrm{P}$ & 1,084 & 1,064 & 1,063 & 1,050 & 1,049 & 1,074 & 1,050 & 1,035 & 1,065 & 1,059 \\
$\Delta \mathrm{S}$ & 1,051 & 1,029 & 1,055 & 1,060 & 1,013 & 1,075 & 1,144 & 0,959 & 1,022 & 0,982 \\
$\Delta \mathrm{T}-\Delta \mathrm{P}$ & $-0,096$ & $-0,038$ & $-0,050$ & 0,044 & 0,014 & $-0,023$ & $-0,003$ & 0,014 & $-0,168$ & 0,014 \\
Conclusion & & & \multicolumn{7}{c}{ Sustainable Growth } \\
\hline
\end{tabular}

(Index Mundi, n.d.-c; Encyclopedia of the Nations, n.d.-a; Encyclopedia of the Nations, n.d.-b; Nation Master, n.d.-a; Nation Master, n.d.-b; Nation Master, n.d.-c; OECD, n.d.-a; OECD, n.d.-b; OECD, n.d.-c; The World Bank, n.d.-a; The World Bank, n.d.-b; The World Bank, n.d.-c; The World Bank, n.d.-d; The World Bank, n.d.-e; The World Bank, n.d.-f; The World Bank, n.d.-g; The World Bank, n.d.-h; The World Bank, n.d.-i; The World Bank, n.d.-j)

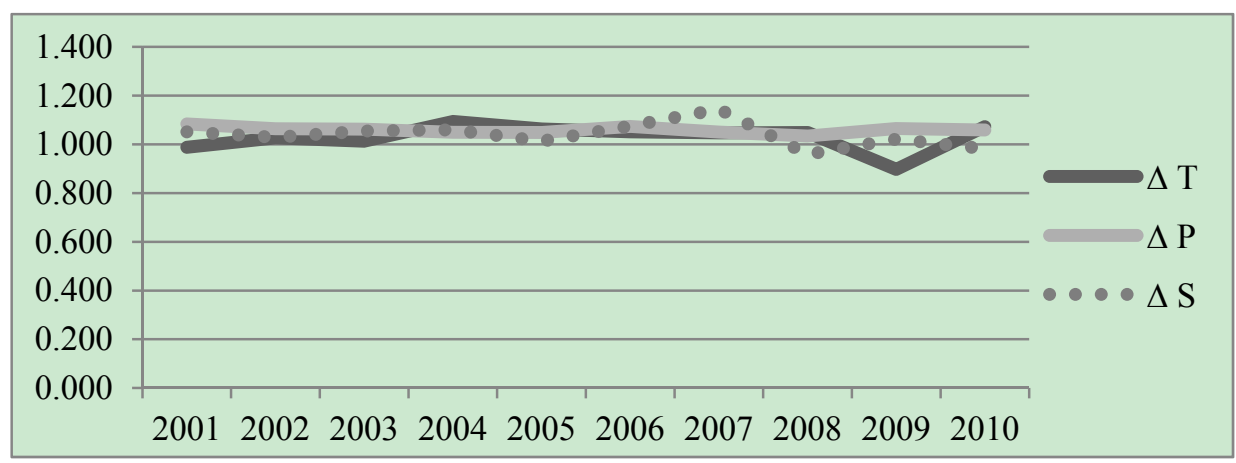

Compiled by the authors

Figure 4. USA, 2000-2010. Sustainability elements $\Delta T, \Delta P, \Delta S$

United States as well passed the sustainability test and together with Germany showed the least amount of fluctuations (see Table 4 and Figure 4). It is interesting to note that population surplus and public expenditure dynamics was almost at all times greater than technological surplus which correlates with common knowledge about social safety net that is provided in U.S. Technological surplus had been fluctuating reaching its lowest in 2009, as we can see the sharp drop started in 2008 around the start time of the world economic crisis. Savings surplus was the least stable components, which also correlates with what is known about U.S. budget deficit and debt problems. U.S. attempted to elevate savings surplus in 2005, however it started to fall sharply in 2007.

\section{Discussion}

We depicted the results graphically in order to visually analyze the results of the sustainability testing (see Figure 5). In addition we compared all the elements of the inequation among countries (see Figure 6).

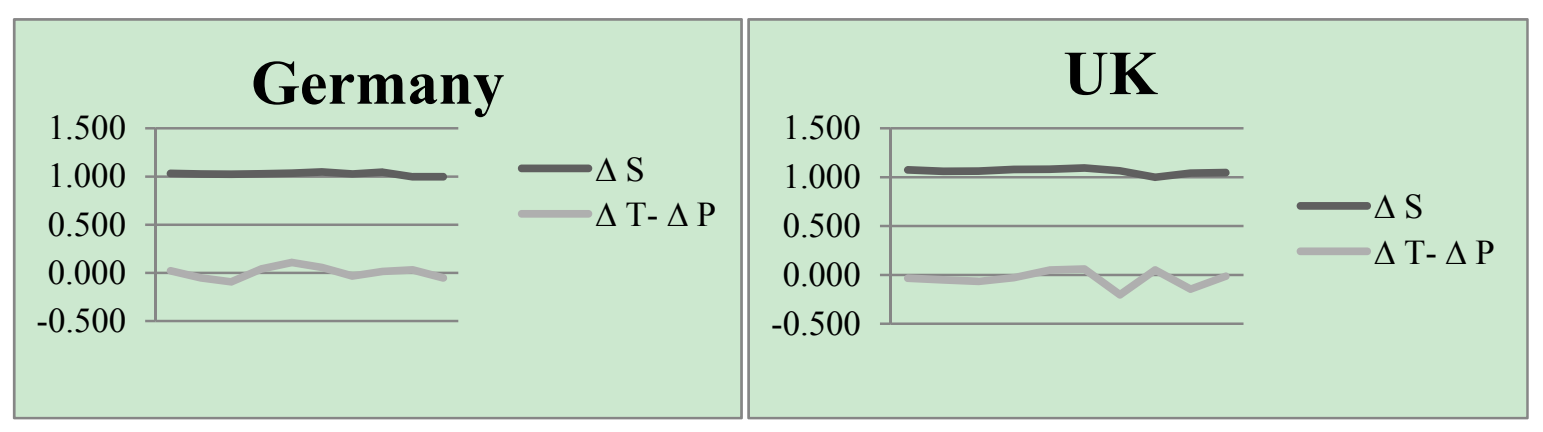




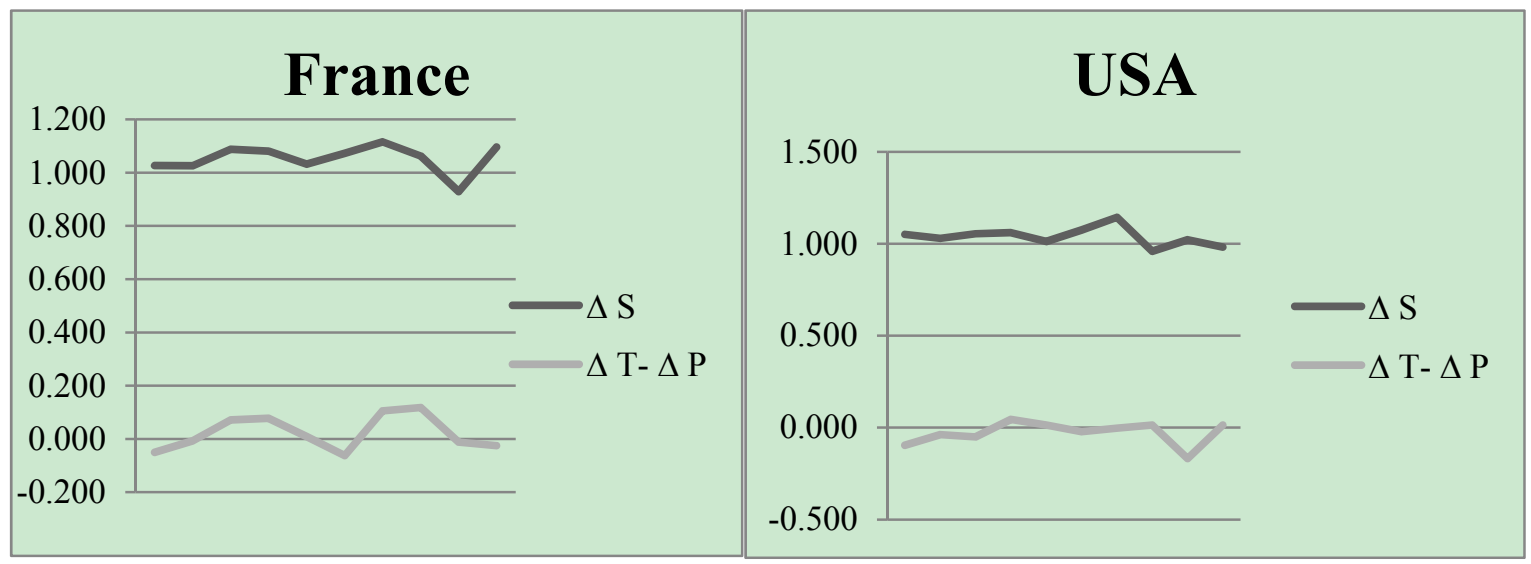

Compiled by the authors

Figure 5. Sustainability testing $\Delta \mathrm{T}-\Delta \mathrm{P} \leq \Delta \mathrm{S}$ presentation for Germany, UK, France, and USA between 2000 and 2010
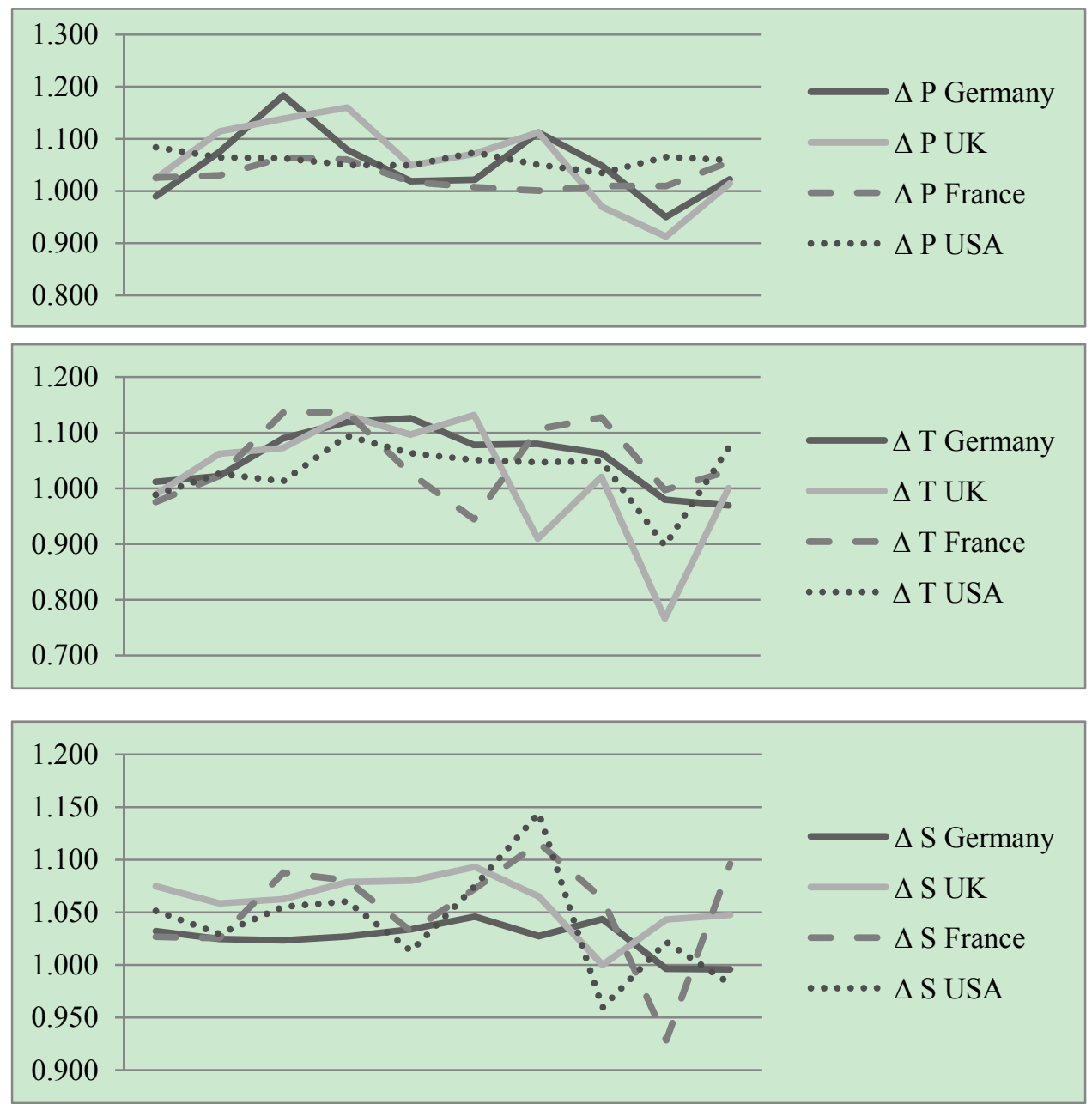

Compiled by the authors

Figure 6. Comparison of elements of the sustainability inequitation

Figure 5 depicts the difference between the two sides of inequation: savings surplus on one side and technological surplus minus population surplus with population spending dynamics. $\Delta \mathrm{T}-\Delta \mathrm{P}$ difference represents equilibrium between investments in current and future generation, difference at zero level means 
equality between the two, positive difference means that technological surplus was greater, negative difference means that public expenditure was greater. The bigger the difference between zero level $\Delta \mathrm{T}-\Delta \mathrm{P}$ and $\Delta \mathrm{S}$ the better, we can simply graphically see the change in savings surplus. In the first decade of the second millennium Germany and USA showed most stability in terms of spreading investments between public expenditures and technology, meaning that out of four countries they managed to sustain the most equilibrium. France and UK had considerable fluctuations. France predominantly had technological surplus over public spending dynamics, while UK had it the opposite way. As far as comparing two sides of inequation and conducting sustainability test - all four countries show desirable results, keeping manageable difference between the two sides of inequation.

Figure 6 depicts comparison of all three elements of inequation that allows us to compare countries more closely in addition to comparison of their growth sustainability. France showed least fluctuations in population surplus and public expenditure dynamics, the growth rate for this element for France had almost not changed in 2010 compared to 2001, which makes absence of fluctuations cautiously strange. They did attempt to lift up the growth rate, but it went down in couple of years, in 2010 the dynamics started to rise again, but not much. USA had almost the same situation; however their surplus was originally higher. It can be seen that USA tried to manage public spending growth rates, however there were small ups and downs along the way, the number they ended up in 2010 is slightly smaller than the number in 2001. Such fluctuations in US are easy to explain by the nature of national budget. UK and Germany showed large and dangerous fluctuations, both countries ended up with almost same growth rate. It is important to note that both of them attempted to lift the public expenditure rates but the attempts were not successful in a long run.

UK showed most fluctuations for technological surplus, after a series of sharp drops and rises, they ended up on the same level. Considering what we know about fluctuation that UK showed in public expenditures, it is possible to say that strategical application of analytical and statistical tools in UK is missing something because these fluctuations show certain degree of ungovernability. Same goes for France. France ended up with slightly higher growth rate for technological progress in 2010 compared to 2001, but showed considerable fluctuations versus stable growth. Germany had stable advance in the rate of the technological progress, however around 2005 it started to fall very slowly. It is possible to presume that it was because of the world crisis that Germany did not manage to sustain even the stable slow down in technological progress and the country ended up with slightly lower rate than it started with. USA had a similar situation for the most part, however after sharp fall, they did lift up the rate and ended up with higher rate in 2010 compared to 2001, their rate was the highest among all four countries.

As far as savings surplus UK and Germany showed least amount of fluctuations, both countries showed rapid drop around the same time, though Germany did not manage to lift the rate up and ended up with lower rate in 2010 compared to 2001 , UK managed to do so and ended up with only slightly lower rate in 2010. Both USA and France experienced large fluctuations in savings surplus. The difference between the two countries was that USA ended up with slightly lower surplus in 2010 compared to 2001, but France managed to significantly raise it.

\section{Conclusion}

All four researched countries - Germany, France, United Kingdom, and United States had a sustainable growth in the first decade of second millennium (between 2000 and 2010). Despite the fact that all four countries show growth dynamics (meaning that there is always a surplus), the question posed by this research is not to assess the growth dynamics, but the sustainability of the development. This paper presented the results of the experimental research, the results correlate with other tests conducted by the authors.

Though all four countries passed the sustainability test, it is possible to say that the concept of growth sustainability has failed to sustain. We have used the experimental inequation to clearly depict the manageability of growth: all four countries maintain relative balance between technological progress surplus and population surplus with public spending dynamics, and most importantly they managed to maintain savings surplus, which was an essential condition of sustainability test. However very considerable fluctuations of elements, including comparative to each other, allow us to draw a conclusion that that growth sustainability of those countries is very vulnerable. Though superficial balance between welfare of current generation and investments in future generations was managed, the real stability was not achieved. Overall, we can see that though some countries develop faster and more stable relative to each other, the concept of balanced sustainable growth is not explored enough on a governmental scale, the complex systems of national economics are managed from the point of view of immediate necessities and short-term strategies. 
It is important to understand that there a lot more research needs to be done in future. We have tested the formula that was developed as the result of broader research, applying knowledge about economics and statistical analysis methods. We realize that economics is not an exact science and national economy of every country is influenced by many factors, but of all the indicators of economic development most indicators show the dynamics of growth, not its sustainability. National debts, lack of resources, technology and infrastructure will influence future generations; weak social welfare and unemployment discourages current generations. Future research must further focus on balancing our growth between the two and developing effective tools for strategically managing national economies.

\section{References}

Barro, R. J., \& Sala-I-Martin, X. (1995). Economic Growth. New York.

Brown, L. R. (1981). Building a Sustainable Society. New York, London: Norton.

Carr, M. (1998). Sustainable Industrial Development. London.

Conroy, C. \& Litvinoff, M. (Eds.). (1988). The Greening of Aid: Sustainable Livelihoods in Practice. London: Earthscan.

Collard, D., \& Pearce, D. (Eds.). (1988). Economics, Growth and Sustainable Environments. Ulph. London.

Pearce, D., \& Redclift, M. (Eds.). (1988). Sustainable Development: Special Issue. Futures, 20(60), 47-56.

Turner, R. K. (Ed.). (1988). Sustainable Environmental Management: Principles and Practice. London \& NY Belhaven.

Encyclopedia of the Nations. (n. d. a). World development indicators [online database]. Retrieved January 20, 2015, from http://www.nationsencyclopedia.com/WorldStats/WDI-growth-rates-industry-value-added.html

Encyclopedia of the Nations. (n. d. b). Health expenditure [online database]. Retrieved January 20, 2015, from http://www.nationsencyclopedia.com/WorldStats/HNP-health-expenditure-capita.html

Goodman, A., \& Sibieta, L. (2006). Public Spending on Education in the UK. The Institute for Fiscal Studies. IFS Briefing Note No. 71. Retrieved from http://www.ifs.org.uk/bns/bn71.pdf

Harrison, F., \& Titova, G. (1997). Land-rent Dynamics and the Sustainable Society. Cambridge Mass (USA): Lincoln Institute of Land Policy. Working Paper.

Hartwick, J. M. (1977). Intergenerational Equity and the Investing of Rents from Exhaustible Resources. American Economic Review, 66.

Hicks, J. R. (1946). Value and Capital. Oxford: Oxford University Press.

Hilbrath, L. W. (1990). Envisioning a Sustainable Society. Learning Our Way Out Albany. New York.

Hotelling, H. (1931). The economics of exhaustible resources. Journal of Political Economy, 39(April), 137-175.

Index Mundi. (n. d. a). United Kingdom: High technology exports (current US) [online database]. Retrieved January 25, 2015, from http://www.indexmundi.com/facts/united-kingdom/high-technology-exports\#TX. VAL.TECH.CD

Index Mundi. (n. d. b). France: GDI (current US) [online database]. Retrieved January 25, 2015, from: $\mathrm{http}: / / \mathrm{www}$.indexmundi.com/facts/france/gross-domestic-income

Index Mundi. (n. d. c). Country Statistical Profile: United States [online database]. Retrieved January 20, 2015, from http://www.oecd-ilibrary.org/economics/country-statistical-profile-united-states_20752288-table-usa

Marien, M. (1989). Driving Forces and Barriers to a Sustainable Global Economy. Futures, 21(6), 563-570.

Nation Master. (n. d. a). Country comparison [online database]. Retrieved January 24, 2015, from http://www.nationmaster.com/index.php

Nation Master. (n. d. b). Country comparison education spending, \% of GDP [online database]. Retrieved January 20, 2015, from http://www.nationmaster.com/country-info/stats/Education/Education-spending 1\%25-of-GDP

Nation Master. (n. d. c). Cash surplus [online database]. Retrieved January 22, 2015, from http://www.nation master.com/graph/eco_cas_sur_of_gdp-economy-cash-surplus-deficit-gdp

Office for National Statistics. (2011). UK Business Enterprise Research and Development, 2010 [statistical bulletin]. Retrieved from http://www.ons.gov.uk/ons/rel/rdit1/bus-ent-res-and-dev/2010/stb-berd-2010.html 
Organization for Economic Cooperation and Development. (n. d. a). Hours worked: Average hours actually worked per worker [online database]. Retrieved January 20, 2015, from http://stats.oecd.org/Index. aspx?DataSetCode $=$ ANHRS

Organization for Economical Cooperation and Development. (n. d. b). Labor productivity levels [online database]. Retrieved January 25, 2015, from http://stats.oecd.org/Index.aspx?DataSetCode=LEVEL

Organization for Economical Cooperation and Development. (n. d. c). National accounts at glance [online database]. Retrieved January 25, 2015, from http://stats.oecd.org/Index.aspx?DataSetCode=NAAG

Page, T. (1977). Conservation and Economic Efficiency. Baltimore, MD: John Hopkins University Press.

Pearce, D., \& Barbier, E. (2000). Blueprint for a Sustainable Economy. London: Earthscan.

Solow, R. M. (1974). Intergenerational Equity and Exhaustible Resources. Review of Economic Studies Symposium, 29-45.

Terentieva, T. V., \& Bobureva, M. A. (2011). Conceptual approaches to interpretation of sustainable growth of business structure. Russian Business, 1(2).

The World Bank. (n. d. a). Data: High-Technology export (current US) DP growth (annual \%) [online database]. Retrieved January 20, 2015, from http://data.worldbank.org/indicator/TX.VAL.TECH.CD

The World Bank. (n. d. b). Data: Research and development expenditure [online database]. Retrieved January 20, 2015, from http://data.worldbank.org/indicator/GB.XPD.RSDV.GD.ZS

The World Bank. (n. d. c). Data: Royalties and fees payment [online database]. Retrieved January 24, 201, from http://data.worldbank.org/indicator/BM.GSR.ROYL.CD

The World Bank. (n. d. d). Population ages 15-64 [online database]. Retrieved January 24, 2015, from http://data.worldbank.org/indicator/SP.POP.1564.TO.ZS?page=2

The World Bank. (n. d. e). Quasi Money, current LCU [online database]. Retrieved January 24, 2015, from http://data.worldbank.org/indicator/FM.LBL.QMNY.CN

The World Bank. (n. d. f). Data: GDP (current US) [online database]. Retrieved January 22, 2015, from http://data.worldbank.org/indicator/NY.GDP.MKTP.CD

The World Bank. (n. d. g). Data: Population. [online database]. Retrieved January 22, 2015, from http://data.worldbank.org/indicator/SP.POP.TOTL/countries

The World Bank. (n. d. h). Spending on education (current US) [online database]. Retrieved January 22, 2015, from http://search.worldbank.org/quickview?name=Public + spending + on $+\% 3 \mathrm{Cem} \% 3$ Eeducation $\% 3 \mathrm{C} \% 2$ Fem $\% 3 \mathrm{E} \% 2 \mathrm{C}+$ total $+\% 28 \% 25+$ of + GDP $\% 29 \&$ id=SE.XPD.TOTL.GD.ZS\&type=Indicators\&cube_no=2\&q term=education

The World Bank. (n. d. i). Data: Health expenditure. (current US) [online database]. Retrieved January 22, 2015, from http://data.worldbank.org/indicator/SH.XPD.TOTL.ZS/countries

The World Bank. (n. d. j). Data: GNI (current US) [online database]. Retrieved January 22, 2015, from http://data.worldbank.org/indicator/NY.GNP.ATLS.CD/countries

UNData. (n. d.). Public Expenditures on Education (\% of GDP) [online dataset]. Retrieved January 20, 2015, from http://data.un.org/Data.aspx?q=education\&d=UNESCO\&f=series\%3aXGDP_FSGOV

\section{Copyrights}

Copyright for this article is retained by the author(s), with first publication rights granted to the journal.

This is an open-access article distributed under the terms and conditions of the Creative Commons Attribution license (http://creativecommons.org/licenses/by/3.0/). 